Cos

\title{
limiar
}

VOL.1 - $N^{\circ} 1-2^{\circ}$ SEMESTRE 2013

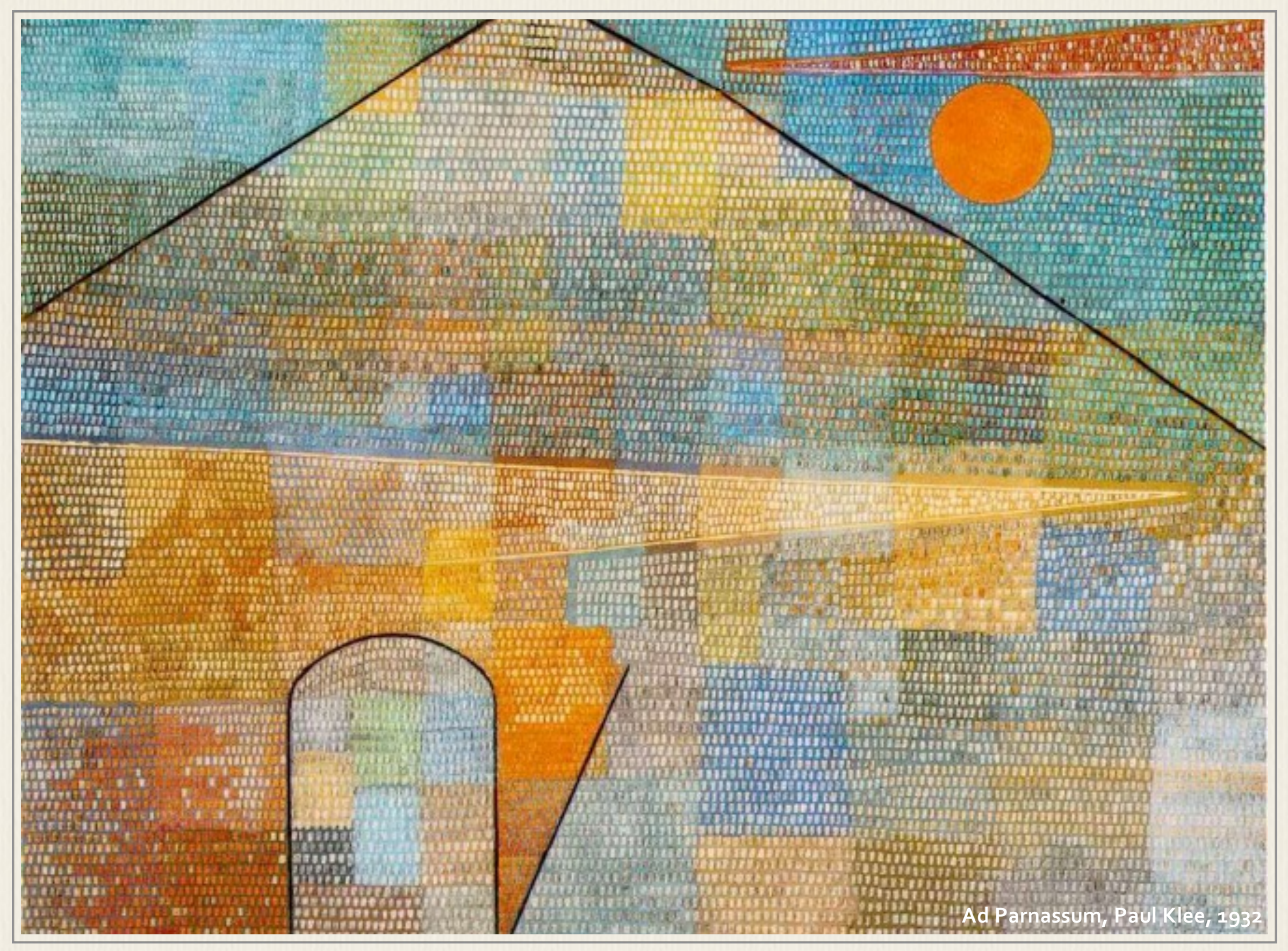




\section{Sobre a Idade Média}

Walter Benjamin

Friedrich Schlegel, em sua "Característica do espírito medieval”, vê o momento negativo desta época na orientação dominante e ilimitada para o absoluto que se faz vigente na arte enquanto fantasia amaneirada (gezierte Phantasie), ${ }^{1}$ na filosofia e teologia da Escolástica enquanto um racionalismo não menos amaneirado (gezierter Rationalismus). É preciso, por meio do contraste com a orientação espiritual asiática, detalhar isso um pouco mais. Também o espírito asiático é assinalado, na filosofia e na religião, por uma imersão desinibida no absoluto. Todavia, sapara-o do espírito medieval um abismo. Nada se encontra mais distante dele, na extrema grandeza da forma, que amaneiramento (Geziertheit). Sua mais íntima diferença para com o espírito da Idade Média funda-se em ter presente o absoluto enquanto conteúdo mais poderoso, a partir do qual desenvolve a linguagem de suas formas. O espírito do Oriente dispõe dos conteúdos efetivos do absoluto, o que já se anuncia na unidade entre religião, filosofia e arte, sobretudo entre religião e vida. Falou-se com frequência que na Idade Média a religião dominava a vida. Mas, em primeiro lugar, a dominadora era a Igreja (Ekklesia); em segundo, entre o princípio dominante e dominado ocorre sempre uma separação. É característico justamente para o espírito da Idade Média que quanto mais radical se manifesta sua tendência ao absoluto, esta é simultaneamente tanto mais formal. $\mathrm{O}$ imenso legado mitológico da Antiguidade ainda não se perdeu, mas falta a medida para seu fundamento real e restaram somente impressões de seu poder: o anel de Salomão, a pedra filosofal, os livros sibilinos. A ideia formal da mitologia: o que confere poder, o mágico está vivo para a Idade Média. Nesta, no entanto, esse poder não pode mais ser legítimo: a Igreja (Kirche) destruiu seus senhores feudais (Lehnsherren), os deuses. Eis aqui, assim, uma origem do espírito formalista da época. Esta procura adquirir poder sobre a natureza destituída de deuses (entgötterte Natur) por meio de um desvio, faz magia sem os fundamentos mitológicos. Surge um esquematismo mágico. Compare-se a prática mágica da Antiguidade com a da Idade Média no reino da química: a feitiçaria antiga utiliza os materiais (die Stoffe) da natureza para poções e ungüentos que possuem uma determinada relação com o reino mitológico da natureza. O alquimista busca - certamente pelo caminho mágico - mas o quê? Ouro. - Algo análogo passa-se com a arte, que surge com o ornamento (Ornament) a partir do mítico. O ornamento asiático é mitologicamente saturado, o 
ornamento gótico tornou-se racional-mágico. Este, porém, atua sobre as pessoas, não sobre os deuses. O sublime precisa aparecer como algo elevado e supremo, o gótico dá a quintessência mecânica do sublime, o elevado, elegante, o sublime potencialmente infinito. O progresso é automático. A mesma exterioridade profunda, nostálgica e destituída de deuses encontra-se no estilo da pintura do Renascimento alemão inicial e de Botticelli. O amaneirado dessa forma fantástica (das Gezierte dieser Phantastik) se origina do formalismo. Onde este formalismo pretende abrir acesso ao absoluto, diminui-se este último em certa medida em escala, e, assim como o desdobramento do estilo gótico só foi possível na estreiteza apertada das cidades medievais, somente o foi também sob uma visão de mundo (Weltansicht) que certamente, no que diz respeito a sua escala de medida, era menor compassada que a da Antiguidade e que a nossa. Na mais alta Idade Média, a visão de mundo antiga foi finalmente em grande medida esquecida e nesse mundo diminuído que restou originou-se o racionalismo escolástico, bem como a nostalgia do gótico que consome a si mesma.

Tradução: Francisco De Ambrosis Pinheiro Machado - EFLCH|UNIFESP

(Original: “Über das Mittelalter” (1916), in: Walter Benjamin. GS II, 132-133.)

A tradução vincula-se ao artigo do mesmo autor, "Romantismo sóbrio: o fragmento "Sobre a Idade Média' de Walter Benjamin 